\title{
The process of abstraction in the creation of meanings
}

\author{
Jesús Martínez del Castillo \\ Department of Philology, Faculty of Business Studies and Tourism, Universidad de Almería, Almería, Spain \\ Email address: \\ jesus.gerardo@ual.es, apofansis@msn.com
}

\section{To cite this article:}

Jesús Martínez del Castillo. The Process of Abstraction in the Creation of Meanings. International Journal of Language and Linguistics. Special Issue: Linguistics of Saying. Vol. 3, No. 6-1, 2015, pp. 11-23. doi: 10.11648/j.ijl1.s.2015030601.13

\begin{abstract}
Linguistics of Saying is to be analyzed in the speech act conceived of as an act of knowing. The speaking, saying and knowing subject, based on contexts and the principles of congruency and confidence in the speech of other speakers, will create meanings and interpret the sense of utterances supplying the deficiencies of language by means of the intellective operations mentally executed in the act of speech. In the intellective operations you can see three steps or processes: first the starting point, intuition or aísthesis; second, the process of abstraction; and third, the inverse: the process of determination or fixing the construct created.
\end{abstract}

Keywords: Human Beings, Human Subject, Speaking, Saying, Knowing, Thought, Intellective Operations

\section{Introduction}

The speaking, saying and knowing subject aims at expressing his meaningful intentional purpose by means of the so-called intellective operations executed individually. With the help of context and the knowledge of things, the subject interprets the sense of words, thus making for the deficiencies he finds in language. The human subject in as much as he knows transforms the sensitive and concrete (the thing perceived) into abstract (an image of the thing perceived), the abstract into en idea (imaginative representation of the thing abstracted), and ideas into contents of conscience (meanings) 1 . The act of knowing starts with an initial intuition on the part of the subject, something material and sensitive. Then the subject transforms what it is given to him through his senses aiming at making it linguistic in a double process, the process of abstraction and creation of a construct, and the inverse, the process of fixing the construct created. Both processes are executed with a series of intellective operations thus constituting the speech act. The first step is constituted with the initial intuition or aisthesis 2, something sensitive and concrete. The second step is the process of abstraction consisting of four intellective operations: selection, delimitation, the creation of a class or an essence, and relation. And the third step consisting in the process contrary to

\footnotetext{
${ }^{1}$ Cf. Martínez del Castillo, 1999, p. 78.

${ }^{2}$ Aristotle, De Anima III, 1, 425a, 14 apud Ortega y Gasset, 1992, p. 128.
}

abstraction, the process of fixing the construct created in the conscience of the individual speaker, ending up in the linguistic expression. To fix the construct created, the subject transforms what he created in his conscience thus transforming it into contents of conscience or meanings. It consists of three intellective operations, giving the construct a name, determination and expression.

\section{The Act of Knowing Aiming at Saying Something}

Intellective operations are aimed at expressing the meaningful intentional purpose of the individual speakers. For a speaking subject, the problem is to say something. The meaningful intentional purpose of the individual speaker constitutes the free determination of the speech act. Linguistic expressions manifest themselves in the procedure used in the conception and expression of things. In order to say something, we as human subjects must create the following things:

- An object to say something of.

- Delimit the object created thus trying to give it reality.

- Specify or define what they want to say of the object created. With this and the previous operation they create a semantic object.

- Create a class of objects to define the object created. With this operation they create a class or category to 
apply it to the semantic object created.

- Relate the object and class created to something previously known.

- Find out a name to represent the construct created, that is, the object and class created.

- Apply the object and class created to things in the world, thus making the construct created real.

- And finally offer the creation made to other speakers, that is, express what they have created made into contents of their conscience in words of a particular language.

All this is executed in the speech act, the act of creating language by a free subject aiming at a particular meaningful purpose, based on the act of knowing and using the means of expression of a language.

\section{An Initial Intuition or Aísthesis}

The human subject, in order to survive in the circumstance they are in, must do something3. The circumstance the subject is in may be hostile or friendly. The first thing the human subject must do is to know about the things surrounding him. The speech act as the performance of the act of knowing is an entirely free act. It consists in transforming what comes up through the subject's senses, something concrete, into something abstract, something liable to be manipulated. What comes up through his senses cannot be but lived, not manipulated. However, human subjects imagine something about what comes to them through their senses in order to transform and manipulate it, if only mentally. The thing transformed into, or created, or fabricated, can be used as a model to modify the world surrounding the cognizant subject. It will be used not only in the particular situation the subject is in but in many other possible future situations.

The act of knowing, as we said above, starts with an initial intuition on the part of the subject. This initial intuition is of sensitive and concrete character: it is sensation, called by Aristotle aisthesis4, something we cannot describe but merely feel or live. Intuition is something we can or cannot have, at the most something we can prompt. It constitutes the condition sine qua non of the act of knowing. This kind of intuition or sensation is something had even by animals. If, for a sensitive being, sensation cannot be manipulated, for the free, creative, cognizant, saying and speaking subject it can be transformed and made into something representing a new thing. The initial sensation (intuition, aisthesis) can be executed in two ways: you can either perform it sensitively, that is, by living it, for example when driving, playing the piano, etc., without the help of words, or by transforming it into something non-concrete and non-sensitive, that is, abstract. The intellective operations manifest themselves in the speech act and in some way or another in languages.

\footnotetext{
${ }^{3}$ Ortega y Gasset, 1994, p. 190.

${ }^{4}$ Ortega y Gasset, 1992a, pp. 128-130.
}

\section{Selection}

The first intellective operation in the properly human knowledge is selecting something arbitrarily from the initial intuition, or selecting the whole intuition under a particular point of view. Now then, starting with this selection, we can make a construct delimiting it somehow; attributing reality to it; giving it an essence or consistency; relating it; constituting it in object of saying; giving it a name; we can define ourselves before the construct created so far, that is, we can say something of it; and determine it thus orientating it to things making it real. With selection we transformed what was sensitive into something abstract thus making the human act of knowing into human proper.

Selection is necessarily the first operation in human knowledge. Out of the continuum of possible relationships of signification or connections, potential aspects, perspectives needing clarification, given or liable to be given in aisthesis, an aspect or the whole sensation is selected thus applying a particular perspective. Aisthesis, concrete, sensitive and material, constitutes the real starting point in human knowledge. Aisthesis is just like a sudden flash prompting the act of knowing. Without it human knowledge would not be given. The human intellective operation of selection consists in the mental transformation executed by the cognizant subject thus considering it, at the same time, both as something different from the initial aisthesis and something different from him himself. Human knowledge thus is an entirely conscious act. The mere fact of selecting constitutes a free act. Before selection human knowledge constituted something affecting me. After selection it is something separate from me. And as we shall see later on, selecting means taking something into consideration, that is, attributing it reality.

Aisthesis or intuition is nothing simple, but sensation, something sensitive the cognizant subject lives out of which he can create many perspectives, connections and relationships of signification. Since aisthesis is sensation or a set of sensations it is necessarily individual. Because of this the cognizant subject has the necessity of explaining it to others or at least to himself somehow. In this way, the cognizant subject transforms his sensation into an explanation of it, something from now on, non-sensitive, that is abstract representing something extracted from the sensitive. The first aspect in this explanation is explaining it to the subject himself, that is, to say, contemplating and thinking of it on the part of the subject. Aisthesis is the first understanding, but sensitive or living understanding. Selection comes after sensitive understanding. A pianist interpreting a symphony must live what he is doing, that sensitive and concrete reality he lives and because he lives it he executes it, reproduces it mentally and sensitively, that is, he selects out of his sensations and turns the thing selected into a new sensation living it by means of the move of his fingers. In this sense you can say that the pianist creates in the execution of something created by someone else. But this creating is nothing but living, reviving and reproducing the sensation he lives at the moment. In the saying subject selection is clearer, since the human subject 
must put elements alien to him between his aísthesis and its expression: words, physical (in speech) and mental (in thought), words not belonging to him in principle, or rather, belonging to him in as much as he takes and accepts them from the tradition thus making them his own.

As a consequence the cognizant subject contemplates four different realities:

- What he feels (his intuition, aisthesis).

- The image he has created to represent what he feels.

- Himself as different from his sensation and the thing he has selected or fabricated. This fact is the base for the creation of human thought and conscience, and

- The words and expressions of the particular language used.

A human being is not pleased with merely living his sensations sensitively. A human subject executes his sensations and transforms them into language, something to be interpreted not sensitively but mentally or intellectually. Human knowledge in principle is nothing but the transformation and elaboration of an initial aisthesis into something new, that is, an elaboration, analysis or abstraction, a selection of something given made something else, something in sensation no longer sensitive but something the product of abstracting from sensation, something by no means concrete. What we abstract, select or extract5 is nothing but something somehow in the aisthesis, something discrete and part of something else continuous and complete. But the thing selected by the cognizant subject is conceived of as something complete and indivisible. Selection is but an approximation to what in itself is understood because it is lived. What we select is nothing but a potential relationship of signification the cognizant subject must build up.

The facts of selection and subsequent rearrangement of facts of experience can be clearly seen in the mode of interpreting a particular fact of experience in particular languages. Although the forms of interpreting reality in a particular language are traditional and thus participated and common in the speech community in question, they constitute an act of knowing, born as an act of knowing, then modified in language use but modified as an act of knowing. You can find examples of different selection starting with a particular fact of experience in the books of general linguistics and anthropology comparing languages with one another. To this respect you can see the works by E. Sapir, B. Whorf and some others6. In every language you can find examples of different selection, for example, in English in the way of counting numbers, either with cardinal numbers or with ordinal numbers. Some years ago, for example, we could see the controversy emerged over the beginning of the $21^{\text {st }}$ century, either the $1^{\text {st }}$, January, 2000 or the $1^{\text {st }}$, January, 2001. Opinions for both options were fiercely defended. The fact

\footnotetext{
${ }^{5}$ For Ortega y Gasset, abstracting means extracting something out of the thing the former is given in. Cf. quotation in footnote no 27.

${ }^{6}$ Cf. to this respect Edward Sapir, 1974 (1921); Benjamin L. Whorf, 1956; Juan de Dios Luque Durán, 2001.
}

was a mere problem of conceiving of the same reality from different points of view, something having to do with the act of knowing and the different modes of thinking implicit. In the end it was a problem about transferring to the real something conceived of. Time and in particular the period of time we call a century, considered as a unit, was conceived of in two ways, absolutely (counting with cardinal numbers), and relatively in an ordered succession (counting with ordinal numbers). Then the different conceptions were transferred to the real, that is, the real thing of counting arbitrary periods of time called centuries was applied under two different perspectives, two mental perspectives never to be mixed up. The problem was in confusing the mental with the real and applying two different conceptions to a real fact.

The usual way of counting is constituted with cardinal numbers. In this type of counting the items counted are considered not in what they really are, but under the perspective of a concept alien to the thing counted, a concept "fabricated", the concept of unit. In this way we do not count men or women, but units representing numeric items transferred to real objects. We do not count twenty-five trees but we mean twenty-five units of the concept tree. The thing we count is not a real thing, but things transformed into abstract things conceived of as units. Because of this, we can count only those things with designation in the real: trees, flowers, cats, rivers, etc. and even those things with no real designation at all. We can say two different types of organization but here again we invent a new concept such as a container (type) in order to count them. However the extent of this use ultimately depends on the language chosen. In Spanish we can say dos organizaciones distintas, and even dos bellezas distintas, etc. When we use such a grammatical procedure we equate all things to "being one and indivisible". Both unity and the contrary, non-unity, constitute things existing only in our mind7. From this perspective it is the same if the thing has designation in the real or not: in both cases designation is created in the conscience of the speaker. What we do then is considering an aspect of reality as if it was "a thing", that is, we "create" "things" in a new way and ignore the traditional concepts in force in the speech community referred to as meanings. This is the historical way of counting, with cardinal numbers.

Moreover, we have another historical way of thinking, counting with ordinal numbers, whose confusion with the previous one at the level of the real gave rise to the controversy referred to above. Counting with ordinal numbers involves considering the things counted in a series of succession, that is, in this type of counting even the concept of unit is considered under the perspective of an "event linked to other events of the same type in a succession". An event is given individually thus being capable of being considered in an order established on its "happening". In counting with ordinal numbers you can see for ideas under the consideration of being counted: first, the unit;

\footnotetext{
${ }^{7}$ For an intellective analysis of the operations implicit in counting, cf. Jesús Martínez del Castillo, 1999, § 3.2 .
} 
second, the event; third, the succession of the event created; and fourth, the order established in accordance with the event stated. Is it the same to apply only one concept, the concept of unit, to things being counted thus annulling any other consideration, as to apply the concept of unit to things considered as events and events ordered and even ordered in a succession annulling as well any other consideration? Not, at all. The English language has words and procedures to express these types of mental connections.

A completely different way of thinking in selecting something from facts of experience can be seen in the so-called Old English, namely, a combination of both procedures explained so far. In the Anglo-Saxon Chronicle, annal 851, the following expression appears, And pý ilcan gēare cōm fēorpe healf hund scipa on Temese-mūpan; literarily, "that year referred to, the fourth half of hundred of ships came to the estuary of Thames", that is, that year referred to, up to three hundred and fifty ships came to the estuary of river Thames. This procedure would not be understood today and even found contradictory with itself. The hundred (hund) is conceived of both with cardinal and ordinal numbers at the same time. In this sense you can divide the concept of hundred in two halves. The first half was not necessary to express in a particular sentence since it is supposed to be mentioned when using ordinal numbers, but the second one had to. So then you take three hundreds complete (with cardinal numbers) and the first half of the fourth hundred, implicitly considering that, since it was an ordinal number, mentioning the second was the limit of the operation of counting. That is, "there came to the estuary of the Thames up to three hundred and fifty ships". The same expression appears in the annal 855 as well: And he ricsode nigontēope healf gear; literarily, "and he reigned so long as the second half of $19^{\text {th }}$ year", that is, "he reigned for eighteen years and a half". However much sense we can look for in these expressions with our traditional mode of thinking (idiomatic context, for Coseriu $^{8}$ ), we shall never be able to find an explanation to its meaning.

Another procedure worth noticing in these examples is the consideration of some large numbers as units. In Old English from number 70 on, the expression hund is added before the number thus giving the idea that it was a very large number. In this way you should say siex-tig nigon and $\bar{a} n$ is hund-seofon-tig. This procedure can be traced back in English today and find expressions as hundreds (OE hund), scores (OE scoru - scora/score), dozens, as plural expressions to be considered as units, expressions and procedure coming from Old English. You can say, How many students do you have? Hundreds; they came in their dozens/by the dozen; or he lived to be three score years and ten. Dozens, is an expression coming from Old Norman French $\left(12^{\text {th }}\right.$ century dozein $\left.(e) s\right)$. This means that the mode of thinking goes beyond the material formation of words.

Selecting from aisthesis is not cumulative. This means that

\footnotetext{
${ }^{8}$ Cf. Martínez del Castillo, 2013, §§ 13.4.10. and ff.
}

a particular form of conceiving of things or apprehending things constitutes a procedure, that is, a mode of thinking. Selection is nothing but the interpretation of aisthesis in the process of changing it into words and reality. Beyond words and expressions it is the way of thinking and the idiomatic context, something having to do as well with the process of creation of designation, that is, the creation of things. Selection is nothing but the interpretation of aisthesis in terms of some ideas, sometimes by the individual speaker, sometimes existing in the tradition, that is, historical ideas used individually, born out of beliefs. In itself selection is unique and indivisible since it is a creation by the individual speaker. In this case we are analyzing particular historical procedures of expression dealing with sensation on the one hand, and with knowing on the other. Both in knowing as in our analysis we are just making a translation out of a sensitive reality into a mental reality thus making it contents of conscience. In our analysis we are just making mental operations consisting in translating something the sensitive into something non-sensitive, something concrete into something non-concrete, something unique into something common, that is, something able to be had or understood by anyone. We can refer to this thing transformed into as an idea, but it is too early in our analysis to use such an expression. Both what the cognizant, saying and speaking subject does and what we are just doing in the analysis of the act of knowing, consist in the same thing, creating ideas. If now we refer to a particular expression as something consisting in combining two or three ideas, we really create here those ideas in order to describe something indivisible in itself. Hence that, on the one hand, knowing or the act of knowing is not mechanic or unequivocal. The same reality and the same selection can give two or more different conceptions of things. On the other hand, the very description of the act of knowing with the ideas constituting it can be made as well differently.

The act of selecting from aisthesis can be made, and in fact it is made, traditional. For cognizant, saying and speaking subjects, historical subjects ${ }^{9}$, limited and contingent subjects, it is easier to repeat a particular form already performed, either by them or learnt from the tradition in which they are active subjects, than starting again whenever they know something ${ }^{10}$. This fact can be verified in language use. Apparently in the English expressions to drive a car and to be a driver there is no difference. But they both reveal a different selection on the part of the individual speakers, selecting one or another form thus creating different realities 11 .

\footnotetext{
${ }^{9}$ Cf. Coseriu, 1985, p. 32.

10 "A man, when is born, will meet forms to live — modes of speaking and thinking, feeling and fabricating ways of behaving both privately and socially-, forms to live he must absorb under the penalty of having to be he himself the one to start anew to invent or create all those forms to live, thus, under the penalty of regressing back to the really primitive moment in humanity and back to be the first man" (Ortega y Gasset, 1996, p. 223) (my translation).

${ }^{11}$ Cf. Martínez del Castillo, 2004, pp. 72-74.
} 


\section{Delimitating Semantic Objects or Establishing a Designation}

The second intellective operation in the act of knowing, once we selected something out of aisthesis or selected the whole aisthesis under a particular perspective, is delimiting semantic objects or establishing a designation. We need to create a semantic object in order to say something of it. At the same time we need to orientate it to the reality constituting a "world", either the world of fiction, for example, a siren, or the physical world, for example, a mountain 12 .

The intellective operation of establishing a designation is an operation always present in human knowledge. There is no object of knowledge unless it is performed in the world in which the cognizant subject is involved. This world, although it is mental in its foundation is pointing to particular things thus constituting reality. Human knowledge involves the transformation of something coming up through the subject's senses into something constituting the object of the imaginative mental rebellion of human subjects in struggle with the circumstance 13. The intellective operation of designation consists in making true the thing apprehended or imagined, the thing known, that is, it means attributing the thing we imagine, the thing we create by imagining, a particular degree of reality in some world, a world which cannot be any world but the world known to us, that is, the historical linguistic world we live in. Since we attribute reality to the thing we imagine, we attribute some limits somehow. We delimit it in some way. This attribution can be limited or unlimited.

Delimiting semantic objects may be perfect when the reality

12 I've chosen siren because it is perhaps more clearly perceived as imaginative, the fruit of imagination, than the rest of objects of knowledge. In effect, speakers will not conceive of that form otherwise. They are nothing but a fictional object. But siren is not more imaginative than mountain, tree, or river, on the one hand and on the other, than justice, agreement, aggression, event, happen, guarantee, veto, reform, danger, suspect, peace, visit, organize, necessity, need, etc. All concepts are the fruit of imagination, all meanings are contents of conscience and all concepts are to be performed in something created, delimited and designated. The topic I am interested in stressing here is that there are some semantic objects the designation of which is more definite, the case of those semantic objects with performance in things in the world, a historical imaginative world, whose existence, in spite of its imaginative and historical condition, is necessary for all speakers, that is, the same as to say, necessary for all cognizant subjects. I am interested in stressing as well that there are other semantic objects the designation of which is known before hand by speakers as created and imaginative, with no designation or possibility of designation in the physical world, such as justice, peace, etc. or siren. 13 Ortega y Gasset says, "Man, in his tackling with sensitive things surrounding him, is enchained to them. [...] But $[\ldots]$ he can imagine he is free $[\ldots]$. This imaginative freedom, means [...] an effective freedom of imagining before sensitive things, before the 'things there' he is enchained in front of. Thanks to imagination [...] man can fabricate [...] a world of imaginative things; or said in other words: he can fabricate a system of imaginative things organized in an imaginative world, $[\ldots]$ he can fabricate innumerable worlds in that way, that is to say, imaginative worlds. Sensitive things he is enchained in front of, do not constitute a world. Properly speaking, they are not things, but life affairs, articulated with one another thus forming a pragmatic perspective. They are made into things when we liberate them from that perspective and attribute them being, that is, a consistency proper to them but alien to us" (1992a, p. 131) (my translation). created keeps an exact correlation with the thing in the world, that is, when both the semantic object created and the reality designate exist in the tradition, or there is a basis for the designation of it in the physical world. It is the case of tree, flower, river. They appear to us as having concrete existence since there are objects in our world denoted with the name of these semantic objects, that is, there is an apparent identity between the semantic classes and the objects designate. The semantic objects, on the one hand, and the semantic classes, on the other, appear to the speaking subject as if they constituted the same reality. But as a matter of fact, both what we say and the thing designate we say something of, constitute objects in our knowledge. We create first what we say and, once created, then and only then, we create the object we speak of. I want to remark this: we create the object we speak of after we created the thing we wanted to say of it. It is possible that we should start with the thing we want to designate. That thing is nothing but fruit of the thing we want to say something of.

The delimitation of a semantic object, for a speaker, may not be problematic when the semantic object and the reality designate exist in our tradition of speaking14. It is the case of cat, for example, since there are many entities in our physical world belonging to the class "cat". These facts make speakers identify the thing established as meaning in their linguistic world, and reality. In these cases there is an identification of the thing thought and the thing meant. Both the thing meant and the thing designate can appear identical with each other. The tree or this tree is something real: there is something in our garden thus constituting something learnt alien to us and our act of knowing.

But delimitation can be problematic when the semantic object and thus the semantic class created appear only as contents of conscience without any possibility of designating anything in the world. It is the case of, for example, beauty, faithfulness, profit. In these cases both the semantic objects designate and the semantic classes created have the same reality or degree of reality, the one given to them by speakers either as a mere individual creation of a cognizant speaking and saying subject in this particular moment, or as a common creation in a speech community. In this case, the delimitation refers to the concepts we use, that is, the means we use to say. As such means of saying they only exist in saying and depend on saying and the saying subject. If we say, for example, this is an area of outstanding natural beauty, we have two different realities, the semantic class denoted (an area of outstanding natural beauty) and the semantic object created (this) to be applied the semantic class created. The semantic class created is something completely different from the semantic object created. They both answer to the need of delimiting a semantic object to say something of and creating something to say of it (the class, concept or category). The fact is that we consider

\footnotetext{
${ }^{14}$ I want to clarify that "things" do not exist but in the tradition. In nature there only exists the continuum we perceive and feel. This continuum is systematized, that is, made "cosmos" in the "traditional" conscience of the cognizant subject.
} 
the semantic object created as something created on the spot with the following implications,

1. If the things denoted with the semantic object (in this case the determiner, this) are many we shall consider them as only one.

2. If the things denoted have reality but only diffusely, that is, if we refer not to things properly but relationships or abstract concepts, we shall consider them as something capable of being said something of, that is, as if they were units or entities.

3. If the things referred to, either if they are many or only one, or if they have designation in real things or in something abstract, will be considered objective, that is, considered as if they formed a unit or «a thing».

Both the thing denoted, that is, the semantic object, and the semantic class created, belong to the world of imagination. They have been created by the cognizant subject in the very act of conceiving of and expressing a new state of affairs. They both are based on the intuition on the things perceived or apprehended.

The establishment of a designation is double. It consists in attributing reality to something created as an object, and delimiting it somehow. The attribution of reality to something selected is an entirely free act. It does not bear any connection with the thing selected or the thing to be said. The cognizant subject attributes reality because he wants to and when attributing it, constitutes it both in an object of saying and object of knowledge. The subject selects what he does because he wants to and delimits it in accordance with his interests. It consists, then, in two operations. One manifesting itself as a living action of the subject saying, that is, as an attribution of reality by the subject, and the other, consisting in the delimitation of the thing he says something of. With this the cognizant subject compromises. This double operation is given in the same intellective operation. We can consider two different things: something is the thing created as reality, something real potentially executable, the objet of saying; and something else, the real extension or delimitation of the thing being created as real, the objet of knowledge. Something is that portion of the continuum of things felt constituting the world we say something of manifesting itself, and something different is the delimitation we make on this. In the example, this cat we can see the effect of something we make real, the semantic object constituted in object of saying, something we separate apart of all possible items of the class of cats, and something different is the concept constituting the essence or consistency as something virtual applicable of all items of the class "cats". But this class or essence or consistency is not applied in its entire completion but in terms of the reality attributed to the semantic object thus making this cat be this one and only this one. The concept "cat" does not exist before saying. It is created by the individual speaker when he wants to say and selects a class of infinite potential designation. The fact of attributing something potentially infinite to a semantic construct, restricts that potential infinite thing to a particular sense thus making it real. When in combination, this is not anything and cat nothing potential: both are made real.
The establishment of a designation with its delimitation implicit is essential in knowing, saying and speaking. A human being is "an entity there" 15 , "coexistence of me, or I, with the circumstance, or the world"16. A human being is together with his circumstance17. In order to survive he must relate with the circumstance he is in, that is, overcome his circumstance. For him, the world does not exist prior to his relating to his circumstance. Because of this, he created the world thus saying of it and compromising, transforming what in principle is nothing but a sensation, aisthesis, linking him to the sensitive. A human being liberates himself from the sensitive by imagining something on the things he is involved in. With this he creates a world more in consonance with his imagery. Things in the circumstance either prevent or make his living easier or more difficult to him. The establishment of a designation with its implicit delimitation, from this point of view, is an intellective operation liberating the human subject from his link to the concrete and sensitive, the thing he rebels against $^{18}$.

The establishment of a designation, thus, is a mental, voluntary, imaginative, intellective function without any base on the real, with the only base on the free behaviour of the speaking subject, who wants to say something, creates something to say and, at the same time, creates something to say something of.

\section{The Creation of a Class or Essence}

Under this heading I include a series of intellective operations, every one with different nature, basically consisting in a creation based on relationships of signification either describing or relating. Now under this heading we are going to analyze the intellective operation I call the definition of a class or essence and in the next one we shall see this operation under the heading of the intellective operation of relation. As a matter of fact, the second one is a mode of the definition of a class or essence.

The purpose of these two operations is the creation of a class or essence and the attribution of it to the construct created mentally so far19. We said of this construct that we selected it out of the aisthesis, attributed reality and delimited it in a particular way. With this the construct created was made into a semantic object. The definition of a class or essence involves two intellective operations as well, the definition of a

\footnotetext{
15 Heidegger, 2002, pp. 57-63.

${ }^{16}$ Ortega y Gasset, 1992b, pp. 46-47.

${ }^{17}$ Ortega y Gasset, 1992b, p. 49.

${ }^{18}$ Ortega y Gasset, 1982, pp. 98-99.

${ }^{19}$ With this expression I refer to the mental construct, not existing in itself but in the mind, we are analyzing. If we say that this construct is not finished, that it is made up of different aspects, and is being made in different steps, this is the result of our analysis. Of course, that construct is nothing, it does not exist, it cannot be separated in its component parts unless in our analysis, since it is an act of knowing. We should not forget, in order to better understand it, it is nothing but contents of conscience. Before it was formed, it was nothing at all. It is our analysis decomposing it in order to understand and explain it.
} 
class or essence and the attribution of that class or essence created to the construct being made, that is, the semantic object created.

The definition of a class or essence is not unequivocal. You can create a class or essence in many different ways. As a matter of fact there are many types of classes or essence created. Considered in the function it performs in the act of knowing, criterion I follow to designate it as such, we can describe this intellective operation as a description or a relation or the indefinite combination of both relation and definition. Here when we say description we mean a state of affairs already performed as it can be considered as something liable to be conceived of as unique. This means that, for example, the establishment of a relation, the typical contribution of adjectives, from the point of view of their intellection, appears as a description based or made on a relation. From the intellective point of view, a description is to be conceived of as the effective verification of a state of affairs liable of apprehension. In this sense, 'young' is the attribution of something ("being a particular mode of being") to someone ("John", for example) of a description ("being a particular mode of being as a state of affairs") based on a relation ("being in the mode of being as a state of affairs referred to youth") 20 .

In this way, when we say relation in the explanation of the definition of a class or essence we mean the consideration of two concepts put together in the act of knowing. Because of this the intellective operation we are going to analyze now, is very complex and it depends entirely on the type of cognizant construct being created.

Given the complexity of this operation, the definition of a class or essence is one of the most important operations in the cognizant act. In this operation we can create either a new class, a class having never existed before, or re-create a traditional class; we can relate a new cognizant construct to meanings already existing in the language and thus known to speakers, either because they, the speakers in question, created them, or the meanings existed in the tradition; either because the speakers in question re-interpret them, or because they determined new cognizant constructs already made and known in terms of new functions created on the spot.

In the definition and attribution of a class or essence anything is possible, but it is at the same time something new, creative and imaginative. Either if we create a new class of objects, or if the class created belongs to a traditional class adapted to the new circumstance, we deal with an interpretation or re-interpretation of something existing. Because of this, the definition of a class or essence can never be the same. It will always answer to new necessities, new meaningful intentional purposes by the individual cognizant subject. If we consider the meanings already performed, that is, traditional meanings, we shall see traditional constructs and procedures in the creation of them, that is, constructs and

\footnotetext{
${ }^{20}$ I consider paraphrasing not as the meaning or proofs of the meaning of an expression, but as "equivalences in the designation" of an expression (cf. Coseriu, 1987, p. 194).
}

procedures common in the speech community only belonging to the particular speech community in question; because of this they will appear repeatedly. But if we consider that the only meaning to be given is nothing else but sense 21 , that the meaning belonging to the norm and system of a language 22 is, the same as with a concept, something abstract or, applied to a language, something virtual, the definition of a class or essence is nothing but an act of abstraction performed on the base of extracting from the real in a speech act. The definition of a class or essence never is alike.

In the definition of a class or essence abstraction plays a decisive role, the concept of which never is unequivocal either The thing abstracted, that is, "extracted"23 out of aisthesis is an arbitrary and capricious one; as such it constitutes a mode of abstracting. We have already seen that the characteristics extracted can be common to some members of a particular class, but they are not necessarily common 24 . Even more: they were formed out of the degree of commonness in them, but on creation. If we extracted only characteristics which are common, we would do a particular mode of abstraction, to be called, to avoid the name induction, "ascending" 25 . But if we put together different cognizant or semantic constructs with one another we would have another type of abstraction, by no means to be called ascending. Speaking of knowledge, relating two concepts to each other is just putting both concepts together and contemplating, that is, looking with the purpose of finding connections in them 26 . In the definition of a class or essence abstraction never is alike nor can it be, nor can it be of the type referred to as ascending. The mere fact of selecting something out of a continuum and the mere fact of putting together two concepts, whatever their nature may be, constitute an act of abstraction. The connections to be found in them are created and added on the significance of the concepts in themselves thus going beyond the concepts.

\subsection{The Creation of a Class or Essence-An Illustration}

\footnotetext{
${ }^{21}$ Cf. the treble distinction in linguistic contents by Coseriu (cf. Coseriu, 1992, p. 96)

${ }^{22}$ Cf. Coseriu, 1981, pp. 118-123.

${ }^{23}$ Cf. Ortega y Gasset, 1992a, p. 64. Cf. footnote, $\mathrm{n}^{\circ} 25$.

${ }^{24}$ Cf. Ortega y Gasset, 1992a, p. 130, and Coseriu, pp. 226-227.

25 This type of ascending abstraction people usually think of when the word abstraction is used, from an intellective point of view involves knowing the items you create beforehand, that is, before those items are conceived of. In human knowledge the procedure is just the wrong way round: first, it is creation, thus making the thing known abstract, and then the application of the thing created to the concrete. First, it is the class or essence and then the creation of the semantic object to be applied the class or essence. Even in the formulation of theories in science, first it is the theory and then the discovery of the data supporting the theory. Once given the theory we abstract from the real but guided by the theory.

${ }^{26}$ Looking for necessary connections in a particular state of affairs or something we arbitrarily combine, constitutes a mode of thinking, the modern or Cartesian mode of thinking, based on intuition (cf. Martínez del Castillo, 2013, §§ 1.3.). To intuit is looking for necessary connections in the thing being conceived of and contemplated. In order to illustrate the idea expressed here, think of the connection in the construct my pencil, that is, the connection between "I" and "pencil", that is, between I as the subject possessing and the pencil as the thing possessed. There is nothing necessary in the elements of the expression, simply a connection established by the speaker.
} 
In order to illustrate the intellective operation of creation of a class or essence we are going to analyse the combination textile beach as opposing nudist beach, the creation of a class started to be used at a particular moment in history and thus new at the time, now inserted in the tradition and thus common and participated in particular touristic contexts in the so-called world English. It usually appears as a notice in particular beaches regulating the use of them. It is thus an advertisement regulating the behaviour of tourists in those beaches.

In the combination we can see the following relationships of signification:

a) A particular semantic construct denoted with noun beach, an item of the semantic class "beach".

b) That semantic construct as it is selected by the speaker in order to say of thus constituting a semantic object.

The first intellective operation in a speech act is selecting a particular semantic object in the real world in order to refer it to the world of meanings, that is, to the linguistic world the human subject lives in. In other words: we select a particular object in the real world and apply something created in our conscience. This selection involves two aspects:

1. Selecting something real. We always speak of real or imaginary things. In this case we present imaginary things as real; and

2. Selecting an aspect of our apprehension, that is, an aspect in our aisthesis, something sensitive, the product of our senses or our intuition. The thing selected out of our aisthesis by the mere fact of being abstracted is extracted out of the thing it is given in 27.

In this way we put together two things: something represented in the real world and something extracted out of a thing in the real world, that is, something sensitive and something mental. The thing mental is applied to the thing sensitive. In both cases selection means separating something out of the thing it is given in. As we said above, in the mere fact of selecting we transform the nature of the thing selected thus making it mental.

In the conception of things the mental is first and then, since we have something to apply to, we look for the thing in the real world to apply the mental thing. This has to do with the motivation in the speech act: the meaningful intentional purpose of the individual speaker. Out of the many items in the class of semantic objects "beach", we extracted one. But this item is not a real object, that is, a particular or singular one, as we are going to see soon. It is possible that in some particular situation the object to say something of is first, that is, that the interest of the speaker is to conceive of an object he does not know. The first operation by the speaker in that situation is to

\footnotetext{
${ }^{27}$ For Ortega y Gasset, to abstract means "extract": "In the thing contemplated and more in general in the thing intuited, our attention fixes one or several elements, that is to say, we pay attention to every one of these. Then, our mind abstracts them out of the rest of things intuited, and extracts the elements fixed, omitting the others The concept extracted in this way is intuition. [...] The Greek called the mental extract its lógos, that is, its 'saying' or 'what it is said of it', because, in effect, words mean those mental extracts" (1992a, pp. 57-58.)
}

classify the object, that is, to ask, what is this? Then, once he has classified the object as, say, a plant or an insect, the speaker will create a class of semantic object adequate to his initial perception to apply it to the semantic object he does not know anything of so far. This way of proceeding is the usual way in the conception of things. It is particularly patent in pure creations or in metaphors. The speaking subject will look for a class or essence and apply it to the semantic object having merely prompted the creation of the semantic class. The creation in our conscience is first, then, the application of it to the real.

The first aspect of selection has to do with designation; the second one, with the thing the cognizant subject adds to the thing perceived, that is, the point of view in accordance with he is going to see the piece of the world chosen to be designated. In this way there is no direct connection in the reality designate and the way that piece of reality is conceived of.

The problem whether or not reality coincides with concepts, meanings or points of view in accordance with reality is to be considered like in a speech act, is not a problem for speakers. It may be a problem for some linguists. In this way a particular reality can be considered differently. For example, cruel denotes a state of affairs to be to be applied of human beings when they want to make harm to somebody else, but for T. S. Eliot it is to be applied of a particular month, April,

April is the cruellest month, breeding

Lilacs out of the dead land, mixing

Memories and desire, stirring

Roots with spring rain ${ }^{28}$.

That is to say, the object selected and represented with the designation of cruel in the example, was selected twice, first as a designation, the mood of the subject represented in the very word cruellest, since the speaker knows that cruel is usually to be applied only of a human sensitive and rational being, and second, as the concept April, a proper name. As a consequence, the connection in the expression and the speaking subject is very far off and relative. At the same time, 'cruel' was selected as a concept (=meaning) denoting "to feel pleasure in causing harm" (a rational and sensitive subject feels pleasure in causing harm to another sensitive and rational subject)".

As a consequence because of this double selection and the application of one to the other, we can also distinguish, both in the first example and in the second, the class of subjects being, respectively, textile (or cruel) and the class, respectively, of beaches (or Aprils), being textile (or cruel).

Following with the analysis of the first example, we can see the next relationship of signification,

c) The semantic construct selected and thus transformed in its way of being, given reality and delimited thus constituting a semantic object, in as much as it is defined

\footnotetext{
${ }^{28}$ T. S. Eliot, The Waste Land, New York, Horace Liveright 1992, verses 1-5.
} 
by the mere fact of applying the meaning of textile to it, that is, in as much a it is meaningfully determined by textile.

Textile is a not an adjective but a noun playing the function of classifying adjectives when in combination. In this sense, textile gives a description of things as they appear in the combination. It gives the sense of creating a new class of objects. It creates a semantic object referring to a new class of semantic objects. The combination means not a semantic object describing a characteristic of the noun beach but a semantic object representative of a new class of objects, textile beaches.

The same explanation can be given in the second example. The meaning of April as a proper name is unique. Any other object of the same class cannot substitute it for, since the class it belongs to, is constituted with only an item. But here in the example it is used as a common noun. That is, if April when referred to in the context of a unit of time is to be considered in a hierarchy, is unique, in the example it is a semantic object referring a class of semantic objects since it is referred to together with other "Aprils" (if the expression is possible). That is, April is used as an item of the class of "Aprils". In the example the speaker (the poet) is not interested in the meaning of the proper noun April but in a meaning going beyond the meaning usually conveyed by the proper noun April. That is, April on the one hand keeps its original meaning and on the other creates a new class with a new meaning. It is about a creation with no basis in the real things. The only basis for it to exist (as a metaphor and the same for all metaphors) is the expression created by the speaking subject, the author of this expression.

In these examples there is no analogy with other examples since they are individual creations and, I would rather say, opportunistic creations. The interpretation of these examples is possible because of the special participation of speakers who look for a sense to expressions, giving for granted that speakers say the truth, - rule of confidence in the speech of others by Coseriu29.

The combination textile beach constitutes thus a class of semantic objects not traditional but made once and now inserted into the tradition of speaking. It denotes a class of semantic objects partly new and partly traditional or said in other words, a new class of semantic objects expressed with traditional means of expression, thus altering them in a particular way and introducing in the language new procedures of expression. Because of this we have to distinguish two types of semantic classes of objects,

I. The class of semantic objects beach belongs to.

In effect, you speak, in the example, of a traditional semantic class of objects thus constituting a common meaning within the speech community. Many semantic objects belong to this class with many potential items to be included in it. Because of this you can designate it as the common class of objects denoting the semantic class of "beaches"; and

\footnotetext{
${ }^{29}$ Cf. Coseriu, 1992a, pp. 107-113.
}

II. The class of semantic objects created in the combination, textile beaches.

In the combination you do not deal with any "area of sand or pebbles beside the sea" but with a type of a beach where you are to swim "in swimming costumes or trunks". But this semantic class of objects is not unique but potential. There are many beaches or there may be many potential beaches to be applied the same condition. This, as a consequence, is a class of semantic objects (textile beaches) included within a larger class of semantic class of objects, the common class of semantic objects referred to above (beaches). The new semantic class is nothing but a restriction of the larger one. The new one means but in terms of the common one as a restriction of it 30 .

So then, so far we know that the example speaks of a particular item of the common class beach, inserted in a lesser class of semantic objects created on the spot in the speech act by the mere fact of determining beach with textile.

But the meaning of the combination is not clear enough with the mere fact of this determination or the mere fact of assigning the semantic object to the semantic class created on the spot in the speech act. For this determination to give sense, that is, for this combination to be possible it is necessary to relate the relationships of signification in the combination and the ones given for granted, just because these are known -what is known is not usually said 31 . The speaker very well knows that the noun textile has to do with cloths in general and that swimming costumes and trunks are made in textiles. On the other hand, he knows that beach refers to a public place where you can practice a particular sport activity, the one of swimming. The speaker knows as well that it is a custom publicly accepted to swim in particular clothes, in swimming costumes and trunks, a type of garment exclusive of this activity. These topics are known and it is not necessary to speak of them. In this way, the combination does not mean that a particular beach be made in textiles but it is about a particular public place, a particular beach reserved to people to perform the sport activity of swimming wearing a particular type of garments, the relationship of signification conveyed with textile. Textile beach thus establishes a relation between the places of sport swimming, the activity itself, to the people performing that activity and the garments to be worn for sport swimming. We can represent the relation established in the following way:

"Beach is to textile as beach is to people, people to sport swimming and sport swimming to textiles".

Or in the sense of inclusion of some concepts in one another, you can say,

\footnotetext{
${ }^{30}$ This fact is analysed by Coseriu in his theory of determination. In the set of determining functions called by him delimiting he remarks the function performed by "specializers", elements specifying a class so as to create a new one within a traditional one. A breakdown lorry belongs both to the class of "lorries" and the class of "breakdown lorries" (cf. Coseriu, 1982, pp. 304-306).

${ }^{31}$ Cf. Coseriu, 1992, pp. 114 and ff.
} 


\section{"Beach: people: sport swimming: garments: textiles"}

Out of these two series of concepts linked to one another, known as background knowledge, we select the first and last ones and omit the rest because they are supposed to be known.

All this constitutes a mental process involving many intellective operations looking for relationships of signification not directly designated in the combination with the aim of finding out a sense to the expression. All these relationships of signification are born in mind when the construct is conceived of, but they are omitted in the expression because they are known and thus unnecessary. That is to say, without the active participation of the intelligent subject in the very act of speech, an act of speaking, saying and knowing and understanding, the combination would not make any sense. The speech act in this way manifests itself as an act of knowing even when, as it is the case, we perform a traditional expression. Whenever we use textile beach, all these mental, intellective operations manifest themselves. A speaker is not a mere mechanical reproducer of set expressions. His knowledge is not, nor can it be, unconscious (in the sense conceived of by psychologists) or innate (in the Chomskyan sense). It is the creative and technical knowledge of a creative subject who creates, performs and executes what the subject himself conceives of in the speech act.

This leads us to the next relationship of signification in the combination we are analysing,

d) The semantic construct selected, transformed in its mode of being, given reality and delimited thus constituting a semantic object, assigned to a particular class of semantic objects included in a larger class of semantic objects, in as much as it is constituted in an object of saying.

In effect, the combination is just a complete and complex piece of information contained in only two words. The contents of it, its lógos, is that it is compulsory to wear swimming costumes and trunks because it is a place to be used by people in general.

This function poses a new problem, what is the basis for the knowledge implicit, stated in the previous relationship of signification? Why do we suppose all the things we said are implicit in the combination?

e) The semantic construct selected, transformed in its mode of being, given reality and delimited thus constituting a semantic object, assigned to a particular class of semantic objects included in a larger class of semantic objects, constituted in an object of saying, in as much as it assigned to the linguistic world known.

The combination has no expressed determiner but merely what we can technically say the zero determiner. This fact speaks of three things:

- There are textile beaches where it is compulsory to wear swimming garments, textile beaches;

- There are beaches, be called as they may, where swimming with no particular swimming garments is permitted (nudist beaches); and

- This beach in particular is one of those textile beaches.

So then, although we do not mention other types of beaches explicitly, with the grammatical zero determination 32, we implicitly mean that there are other beaches and other types of beaches. The combination, then, denotes a whole linguistic world known thus specifying and clarifying the expression used.

But the interpretation of the combination is not still complete. The object of saying we have stated in the previous paragraphs must be seen under a particular point of view. As we said earlier, the object of saying needs something to say of. The object of saying needs the means to create something to say of it, that is, the content to say. In this sense the combination conveys the following relationships of signification,

f) The semantic construct selected, transformed in its mode of being, given reality and delimited thus constituting a semantic object, assigned to a particular class of semantic objects included in a larger class of semantic objects, constituted in an object of saying, assigned to the linguistic world known, in as much as it is constituted in the object of knowledge.

In effect, we took the traditional meaning and designation of beach as a base of the construct created. On this semantic construct we established all relationships of signification stated so far. We selected it and as a consequence we transformed it in its way of being, that is, we created a semantic object; we semantically determined it in the sense conveyed in textile. We referred it to a class of semantic objects and once we created this one, we restricted it to a new one established as a lesser class included in the first one. We analysed it as to the determination it conveys. We constituted it in an object to say something of. And once again with the combination of both words considering the traditional meaning of them we created a long message thus constituting it in object of knowledge.

But now we must relate the construct created so far with other meanings existing in the language constituting with them what Coseriu calls a speech universe33. In this way we have to remark the following relationship of signification,

g) The semantic construct selected, transformed in its mode of being, given reality and delimited thus constituting a semantic object, assigned to a particular class of semantic objects included in a larger class of semantic objects, constituted in an object of saying, assigned to the linguistic world known, constituted in the object of knowledge, in as much as it is inserted into a speech universe.

\footnotetext{
32 Determination is an intellective operation having to do with knowledge thus executed at two levels of speaking: first, it has to do with knowing in itself, something prior to speaking, and second, with the execution of speech in particular languages. This means that in a speech act determination is wider than languages. In languages determination appears grammatically with the so-called determiners. Cf. Coseriu 1982, pp. 290-319.

${ }^{33}$ In 1962 Coseriu called this determining function "a universe of discourse" (cf. 1982, p. 318). Later on in 2006 he justified the change of name to a speech universe saying that it is about "the basic and fundamental modes of knowing of human knowledge" (cf. Coseriu 2006, p. 73).
} 
In effect, when something is ordered or prohibited there are reasons or, especially, there is an authority capable to do that. And this is the last relationship of signification in the example. We must relate it, in order to get sense out of it, to other semantic objects or meanings existing in the world of knowledge the speaker is involved in. The combination deals with a precept or administrative regulation, something known in the world of knowledge the speakers to whom the message is addressed to, know. This relationship of signification justifies and makes the statement implicit in that particular speech universe true. The combination gets sense if we suppose that there is an authority ruling the message we have analysed so far, that is, if we include the statement implicit into the speech universe concerned.

And with this relationship of signification the combination gets sense: textile beach indicates and represents as a matter of fact one of the many regulations ruling the use of beaches and this beach in particular. The announcement textile beach is not informative: it is a precept, a pragmatic aspect ruling the world in which the speakers addressed to are in. In this sense what the announcement says is true, since this linguistic expression is given in that speech universe in which regulations, prohibitions and precepts are in force, that is, the speech universe of common experience in social affairs.

\section{Relation}

The intellective operation of relation has the same function as the operation of creation of a class or an essence. Relation is a type of creation of a class or essence. It consists in connecting, that is, putting together two concepts. The connection between the concepts related is not necessary but created by the speaker, based on the many possible relationships he may have created previously, sometimes based on the knowledge of real things 34 but the great majority of times the connection between both has no foundation at all. It is the cognizant subject the one who creates the connection. Once the connection is created somehow it is applied to the cognizant construct fabricated so far.

In the intellective analysis of expressions relation appears as a description, that is, a state of affairs constituted as the effect of putting together two concepts, that is, as something conceived of or intuited. The application of relation to the cognizant construct created so far, from the point of view of its intellection, is the operation giving a descriptive value to the construct in question. Relation appears in combinations as something made.

As in the case of definition and attribution of a class or essence, relation is very varied. The nature of relation depends, as with the creation of a class or essence, on the type of semantic construct we try to conceive of. The procedure of

\footnotetext{
${ }^{34}$ I mean the linguistic world, a historical world formed and in force in the speech community, a world of "things" the ultimate motivation of which is purposefully

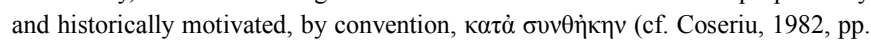
13-59).
}

connecting, that is, putting two things together, is an entirely free act with no basis on things, not admitting any limitation. Because of this you can create any type of cognizant construct. The key to the interpretation of this type of creation is in the rule of linguistics of saying adopted here, the meaningful intentional purpose of the individual speaker, a rule to be inserted into the rule of tolerance and confidence in the speech of others in linguistics of speaking by Coseriu 35 , and sometimes and to a certain extent to the rule of correction. A semantic construct conceived of with similar linguistic and grammatical settings can have different and even opposing signification. Speakers know this fact very well. To interpret these types of semantic constructs speakers will not usually turn their eyes back to analogy but basically to designation and congruence based on the rule of confidence in the speech of others.

For example, the following expression from a logical point of view and due to the knowledge of things, can be analysed as logically contradictory in its terms ${ }^{36}$,

There is a new star in the universe

This expression has sense because, once it has been created, the cognizant speaker looks for a sense. The sense it is attributed to, is historical, that is, one of the many possible senses the expression can have but the only one possible and thus accepted today in the speech community. The nature of an expression is always the same, a creation made by the speaker.

Because of general knowledge we know that it is impossible that today there should appear a new star on the firmament, impossible for a star to exist today that yesterday it had not, that if today we discover a star not existing yesterday, this does not mean that the star is new, and if the light of the star comes up today, it does not mean either that the star is new. If today we relate an item of the class "star" to the signification of "new", we have to look for a sense. We can interpret the combination if we consider the semantic object involved in itself as an object of knowledge and relate it to the consideration of being known, "a star is new in so far as it is known". In this sense, out of an impossible expression, we have created and found a possible sense, that is, we got sense out of its terms.

With this, we have just made an interpretation of a state of affairs without any necessary connection in the things

\footnotetext{
${ }^{35}$ Coseriu says: "we will always suppose that the thing said has a sense thus being congruent with things somehow. If the type of congruence given in the expression is not the usual one, we will suppose another type of congruence. If the thing said cannot be meant, then the speaker must mean something else" (Coseriu, 1982, p. 123) (my translation). He says about the rule of confidence in the speech of others: "The rule of congruence manifests itself - indirectly — in the rule of tolerance: the speaker hopes that the others should speak sensibly and congruently. Because of this, speakers will not reject the incongruous, but will accept it while trying to interpret it as something congruent" (Coseriu, 1992a, p. 273) (my translation).

36 In set phrases and expressions in languages, you can find expressions contradictory in their terms. For example, in Spanish you should say, no vino nadie, with the same meaning but different use as, nadie vino. The former is contradictory in its terms, since double negation affirms in logic. Linguistic expressions are not logical but purposefully and historically motivated, that is, they are conventional, accepted by speakers, Cf. footnote 34 .
} 
involved either real or mental. There is no necessary connection in the fact that a start is known and the semantic object referred to. From a conceptual point of view they represent two different things. In order to combine "star" and "new" we looked for a connection, not necessary but arbitrary, a historically motivated connection accepted in our speech community, the fact that the star in question has been known only recently. Because of this connection we looked for a sense. It is a free connection and because of this it is an abstract connection, only existing in our minds as something invented or fabricated. The type of abstraction used is not the one looking for things in common in the things we know, the one we called ascending abstraction. It consists in adding something in order to connect both the reality in the semantic object "star" and the state of affairs denoted in "new" thus giving for granted that both concepts can get sense with the connection invented, the result of having put together the reality of both elements in the combination. In this way, this type of abstraction was created extracting something out of both concepts in the combination, the one describing the semantic object (star), adding to it the consideration, extracted from the meaning of 'new', that it has been known recently. Thus the thing added mentally is constituted in the sense of the expression. The thing said in the combination is nothing in connection with 'new' or 'star', but the fact of "a star having been known recently".

The relationships of signification manifesting in the example can be shown in lexematic analysis. In the description of the classeme 37 of the adjective 'new' we can introduce the connection added, putting together both concepts. If we accept the procedure of restriction in the notation of the classeme, we can represent the meaning of the adjective, an element with predicative as well as descriptive character, in the following way,

$$
\text { 'new' }=\{/ \text {-LIVING: known/ + /OF AGE: short/ }\}
$$

That is to say, 'new' in, there is a new star in the universe, conveys a different relationship of signification in contrast with other uses of 'new', the most usual ones and the simplest ones from the point of view of their intellection. 'New' in the example is to be applied of the aspect added to the combination, not of the semantic object, a mental relationship of signification looking for a sense to the combination.

Examples like this one, can be very frequent in the language. They can show different relationships of signification in relating the elements in the combination they form. These can evince other types of connection. For example, in the higher officers in the rank, the adjective 'high' is specified in the meaning it conveys with the state of affairs denoted in rank. "Some officers are in a higher degree of importance in the

\footnotetext{
${ }^{37}$ In structural semantics lexemes, that is, lexical words, are usually analysed as a set of features or semes. A lexeme thus has the following structure of signification, lexeme $=\{/$ classeme $/+/$ specific semes $/\}$. A classeme denotes the lexical class the lexeme says something of, for example / \pm human/, / \pm concrete/. Specific semes define lexemes in connection with other lexemes thus forming a lexical field (cf. Bernard Pottier 1974, apud Martínez del Castillo, 2013b, p. 88).
}

rank". The relationship of signification added is not usually known thus it was necessary to express it in the combination (in the rank). In, the same old story, the connection added is the one we have explained earlier, "the story is old in so far as it is known" ("old' = \{/-LIVING: known/ + /OF AGE: advanced $/\}$ ). A senior officer, is someone who is officer because "he has been in service for long". That is, thanks to the intellective operation of connecting the elements in a combination adding new relationships of signification, examples like these can be understood.

A different type of relationship of signification can be seen in the following examples with infantile:

- He was infantile (for example in, he was destructive, sullen, infantile) 38 .

- Infantile actions (for example in, some infantile actions survive into adulthood) 39.

- Infantile in infantile clothes, infantile paralysis.

We can compare the examples and see that in the first example the adjective infantile says something of a particular person, something fitting perfectly to the meaning of both elements in the combination; in the second, the adjective is not applied of persons but of something proper of persons, that is, the adjective needs the help of something in the noun denoting something in connection with persons thus establishing a relation between persons and their actions or properties: persons in this sense disappear but keeping a direct connection with the object the adjective infantile is properly to be applied of, the thing designate, actions (or properties). With this procedure, infantile refers to person but indirectly; and in the third, the adjective is to be thought of in terms of the people using those clothes and suffering from that disease, that is, something the connection with infantile is created on the spot by the cognizant subject.

That is, in the first case, the adjective and the noun to be combined with relate to each other directly. Infantile says something of a person; in the second, the adjective is applied of something implicit in the noun it is combined with. It says of something implicit in persons, something we know empirically; and in the third case, infantile, an adjective to be applied of persons, is not applied of persons but of things to be used by persons. That is, the intellective operation of relation, consisting, roughly speaking, in adding something to the combination, is necessary to get sense out of these examples. If these examples were to be considered in terms of real things, in terms of the semantic objects they denote we should have to say that the second and third examples are incongruous, that is, they did not fit with the meaning of each other 40.

\section{Conclusion}

Abstraction is a process of mental actions aimed at creating meanings. Meanings, from this point of view, are contents

\footnotetext{
${ }^{38}$ Collins Cobuild English Language Dictionary.

${ }^{39}$ Collins Cobuild English Language Dictionary.

${ }^{40}$ Cf. other examples in Spanish in Jesús Martínez del Castillo, 2004, pp. 114-121.
} 
conscience, something born in the interior of speakers and in accordance with the nature of speakers. Since speakers are free and absolute, abstraction is varied and multiform, always new, an instrument a priori of knowing and language.

\section{References}

[1] Coseriu, E., Principios de semántica estructural, Madrid, Gredos, 1981 (1977).

[2] Coseriu, E., Teoría del lenguaje y lingüística general: cinco estudios, Madrid, Gredos, 1982 [1962].

[3] Coseriu, E., Gramática, semántica, universales. Estudios de gramática funcional, Madrid, Gredos, 1987 [1978].

[4] Coseriu, E., El hombre y su lenguaje, estudios de teoría y metodología lingüística, Madrid, Gredos, 1985 [1977].

[5] Coseriu, E., Competencia lingüística: elementos de la teoría del hablar, Madrid, Gredos, 1992 [1988].

[6] Coseriu, E. y Ó. Loureda: Lenguaje y discurso, Pamplona, Eunsa, 2006.

[7] Coseriu, E. Lingüística del texto. Introducción a la hermenéutica del sentido, Arco/Libros, 2007.

[8] Di Cesare, D., Wilhelm von Humboldt y el estudio filosófico de las lenguas, traducción de Ana Agud, Anthropos, 1999.

[9] Heidegger, Martin, El ser y el tiempo, RBA Editores, 2002 [1944].

[10] Humboldt, W., «Ueber die Verschiedenheit des menschlichen Sprachbaues und ihren Einfluss auf die geistige Entwickelung des Menschengesschlechts» trad. Ana Agud: Sobre la diversidad de la estructura del lenguaje humano y su influencia sobre el desarrollo espiritual de la humanidad, Madrid, Anthropos y Ministerio de Educación y Ciencia, (1990) [1836].

[11] Luque Durán, Juan de Dios, Aspectos universales y particulares del léxico de las lenguas del mundo. Granada: Granada Lingvistica, 2001.

[12] Martínez del Castillo, Jesús, La intelección, el significado, los adjetivos, Universidad de Almería, 1999.

[13] Martínez del Castillo, Jesús, Significado y conocimiento: la estructura de significación de los adjetivos subjetivos, Granada:

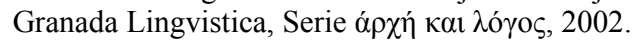

[14] Martínez del Castillo, Jesús, La lingüística del decir. El logos semántico y el logos apofántico, Granada: Granada Lingvistica,

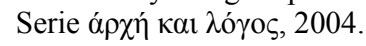

[15] Martínez del Castillo, Jesús, «Hablar, decir y conocer: el acto lingüístico», Oralia, 11 (2008): 375-97.
[16] Martínez del Castillo, Jesús: «El logos semántico y el logos apofántico» Enérgeia I, Online-Zeitschrift für Sprachwissenchaft, Sprachphilosophie und Sprachwissenschaftsgeschichte. 2009: 50-80.

[17] Martínez del Castillo, Jesús: Las relaciones lenguaje-pensamiento o el problema del logos. Madrid: Bilbioteca Nueva, 2010.

[18] Martínez del Castillo, Jesús, Sobre las categorias, Buenos Aires, Deauno.com, 2011.

[19] Martínez del Castillo, Jesús, ed. Eugenio Coseriu (1921-2002) en los comienzos del siglo XXI, 2 vols. in Analecta Malacitana, Anejos/86, 2012.

[20] Martínez del Castillo, Jesús: Psicología, lenguaje y libertad, in Analecta Malacitana, Anejos/89, Universidad de Málaga, 2012.

[21] Martínez del Castillo, Jesús: Modes of Thinking, Language and Linguistics, in Analecta Malacitana, Anejos/94, 2013, Universidad de Málaga.

[22] Martínez del Castillo, Jesús: English Semantics and Lexicology, Universidad de Almería, Almería, 2013b.

[23] Ortega y Gasset, José, La idea de principio en Leibniz, Alianza Editorial, 1992a [1958].

[24] Ortega y Gasset, José, ¿Qué es conocimiento?, Alianza Editorial, 1992b [1984].

[25] Ortega y Gasset, José, Sobre la razón histórica, Alianza Editorial, 1996 [1979].

[26] Ortega y Gasset, José, Goethe, Dilthey, Alianza Editorial, 1982 [1958].

[27] Ortega y Gasset, José, «El decir de la gente: la lengua. Hacia una nueva lingüística» in El hombre y la gente, Alianza Editorial, 2001 [1957].

[28] Ortega y Gasset, José, «El decir de la gente: las 'opiniones públicas', las 'vigencias sociales"”. El poder público» in El hombre y la gente, Alianza Editorial, 2001 [1957].

[29] Ortega y Gasset, José, "En torno al coloquio de Darmstadt", in Meditación de la técnica y otros ensayos de ciencia y filosofía, 2002 [1982]: 192-233.

[30] Ortega y Gasset, José, “Apuntes para un comentario al banquete de Platón", Obras completas, IX, Taurus, 2009: 729-758.

[31] Edward Sapir, El lenguaje, introducción al estudio del habla, México: Fondo de Cultura Económica,

[32] Whorf, Benjamin Lee, Language, Thought and Reality, J. B. Carrol, (ed.) Cambridge, Mass, The MIT Press. 